\section{Black Polyethylene Tunnel Covers Affect Plant Production and Quality of Sweetpotato Transplants}

\author{
D.R. La Bonte and A.Q. Villordon \\ Department of Horticulture, Louisiana State University Agricultural Center, \\ Louisiana Agricultural Experiment Station, Baton Rouge, LA 70803
}

\author{
J.R. Schultheis and D.W. Monks \\ Department of Horticultural Science, North Carolina State University, Box \\ 7609, Raleigh, NC 27695
}

Additional index words. Ipomoea batatas, transplants, propagation

\begin{abstract}
The influence of a black polyethylene tunnel cover (BTC) was evaluated for its effect on quantity and quality of sweetpotato [Ipomoea batatas (L.) Lam.] transplants in plant beds in Louisiana and North Carolina. Use of BTC increased production of 'Beauregard' transplants from $63 \%$ to $553 \%$ in comparison with the bare ground control. 'Jewel' was less responsive; BTC treatments increased transplant production by at least $48 \%$ in Louisiana over the bare ground control, but no increase was observed in North Carolina. Individual transplant weight was at least $34 \%$ less in BTC treatments than in the control. The first harvest of cuttings in BTC beds was at least 14 days prior to that in control beds. Transplant quality was assessed as yield of storage roots in repeated trials that extended throughout the normal growing season. Yield of storage roots was not affected by BTC in early season plantings, but was frequently lower for BTC treatment transplants in middle and late season plantings. We therefore do not recommend this method as a means of increasing sweetpotato plant production from bedded roots.
\end{abstract}

A typical sweetpotato grower in the southeastern United States requires $\approx 4$ million transplants to produce a crop on 120 to 140 ha (La Bonte and Cannon, 1997). A grower must retain $\approx 1.2 \mathrm{MT}$ of roots per ha planted, or $\approx 8 \%$ of the previous-year's crop, to generate an adequate supply of transplants. Growers typically initiate sweetpotato propagation beds in late February or early March and cover the beds with black or clear polyethylene mulch to raise soil temperature and promote early sprouting and transplant emergence. The mulch is removed when sprouts reach the soil surface (Wilson and Averre, 1989). Various clear polyethylene and spunbonded polyester row covers also promote early transplant production (Porter, 1991) and increase transplant weight in sweetpotato (Walker and Randle, 1986).

Received for publication 29 Mar. 1999. Accepted for publication 6 Aug. 1999. The research was supported by funds from the Louisiana Sweet Potato Advertising and Development Commission (LSPADC), and by state and matching funds allocated to the Louisiana State Univ. Agricultural Center (LSUAC), the North Carolina Agricultural Research Service (NCARS), and the North Carolina Cooperative Extension Service (NCCES). Use of trade names in this publication does not imply endorsement by LSPADC, LSUAC, NCARS, or NCCES of products named nor criticism of similar ones not mentioned. We gratefully acknowledge the technical assistance of Dennis Adams and Robert Mills. The cost of publishing this paper was defrayed in part by the payment of page charges. Under postal regulations, this paper therefore must be hereby marked advertisement solely to indicate this fact.
However, in neither study did various row cover treatments increase transplant production in comparison with black polyethylene mulch.

Growers are now switching to more costly, virus-tested, foundation seed stock and tissueculture-derived plant material. Thus, a practical means of increasing plant production could offset the higher prices now paid for seed stock and reduce the amount of seed that must be saved for transplant production. The objective of this study was to investigate the effect of BTC on quantity and quality of transplants. Quality was evaluated as root yield over a normal growing season.

\section{Materials and Methods}

Effect of black polyethylene tunnel cover (BTC) on transplant production from 'Beauregard' and 'Jewel' sweetpotato roots was assessed in a randomized complete-block design experiment with three replications in Baton Rouge, La., in 1992 and 1994, and five replications in Clinton, N.C., in 1992 and 1993. Each plot in Louisiana was $2.5 \mathrm{~m}$ long and $0.3 \mathrm{~m}$ wide on raised beds $1.2 \mathrm{~m}$ apart, while in North Carolina each plot was $1.5 \mathrm{~m}$ long and $0.3 \mathrm{~m}$ wide on raised beds $1.5 \mathrm{~m}$ apart. In Louisiana, 60 'Beauregard' and 55 'Jewel' roots weighing a total of $18 \mathrm{~kg}$ were placed in each respective plot, while about half this number and weight were used in North Carolina. All treatments received $13 \mathrm{~N}-5.7 \mathrm{P}-10.8 \mathrm{~K}$ at $338 \mathrm{~kg} \cdot \mathrm{ha}^{-1}$. The fertilizer was initially topdressed and incorporated into $5 \mathrm{~cm}$ of soil used to cover the roots; subsequent topdressed fertilizer and irrigation were supplied as needed. Black polyethylene $(32 \mathrm{~mm})$ film mulch (for Louisiana, Ken-Bar, Reading, Mass.; for North Carolina, AEP Plastic, South Hackensack, N.J.) was placed directly on the soil surface of all plots in Louisiana on 17 Mar. 1992 and 29 Mar. 1994 and removed $\approx 30 \mathrm{~d}$ later when sprouts reached the soil surface. In North Carolina, roots were bedded on $10 \mathrm{Apr}$. 1992 and 30 Mar. 1993 and the film mulch was removed $\approx 30 \mathrm{~d}$ later.

Two treatments were applied to each clone after the film mulch was removed: 1) BTC was supported by galvanized steel wire hoops 38 $\mathrm{cm}$ over the bed with $25-\mathrm{cm}$ slits spaced every $25 \mathrm{~cm}$ and anchored by soil, and 2) a bare soil control. All control plots were harvested when plants were $\approx 23$ to $25 \mathrm{~cm}$ tall. In 1992, BTC plots in Louisiana were uncovered when plants were $\approx 21 \mathrm{~cm}$ tall for a 5-d, full-sun exposure, enabling plants to gain pigmentation (deetiolation) before cutting. In North Carolina there was no acclimation period before harvest. In 1993, BTC plots in North Carolina were uncovered for 3-5 d when plants were $\approx 23 \mathrm{~cm}$ tall. In 1994, BTC plots in Louisiana were uncovered for $10 \mathrm{~d}$ when plants were $\approx 18$ $\mathrm{cm}$ tall. The length of full-sun exposure in BTC treatments was increased during the 3year study in an attempt to prevent yield declines in BTC transplants. All plants were harvested from BTC plots and plants $\approx 23 \mathrm{~cm}$ or taller were retained, counted, and weighed. The BTC treatment was reapplied immediately after each cutting. Nearly all cuttings were made before 15 July.

Plants from all treatments were transplanted in early to late May (first planting), late May to mid-June (second planting), and late June to early July (third planting). Transplants for the control treatment were sometimes obtained in ancillary beds of the same clone. Twenty transplants per plot were placed $0.3 \mathrm{~m}$ apart within rows and $1.2 \mathrm{~m}$ between rows $(1.1 \mathrm{~m}$ in North Carolina) in a randomized complete-block design with four replications. Commercial sweetpotato cultural practices were followed (Boudreaux, 1994; Wilson and Averre, 1989). Roots were harvested at maturity 97 to $121 \mathrm{~d}$ after transplanting. Yield was calculated for the commercially important U.S. no. 1 grade roots (roots 5.1 to $8.9 \mathrm{~cm}$ diameter and 7.6 to $22.9 \mathrm{~cm}$ long). Yield of other grades was omitted because treatments did not alter their weight appreciably. All data were analyzed by analysis of variance using the GLM procedure of SAS (SAS Institute, Cary, N.C.). Year and location were considered separately because the protocol for the BTC treatment varied for location and year. Means for each variable were separated using LSD at $P \leq 0.05$.

\section{Results and Discussion}

Yield of transplants. In Louisiana, cuttings were harvested four (1994) and six (1992) times from BTC treatment beds vs. three harvests of the control beds in both years in Louisiana. A longer acclimation period for BTC treatments in 1994 reduced the number of harvest dates. The first harvest of cuttings in 
BTC treatment beds was $28 \mathrm{~d}$ (1992) and $14 \mathrm{~d}$ (1994) prior to plant cutting in control beds (Table 1). In North Carolina in 1992, cuttings were harvested four times from BTC treatment beds vs. two times from control beds. A longer acclimation period in 1993 reduced the number of harvest dates for BTC treatment beds to three; control beds of 'Beauregard' and 'Jewel' were harvested two and three times, respectively. The first harvest of cuttings in the BTC treatment ranged from $37 \mathrm{~d}$ (1992) to $14 \mathrm{~d}$ (1993) prior to plant cutting in control beds. Our data demonstrate that BTC treatments hastened transplant production in comparison with black polyethylene mulch controls. The present study, however, did not include any perforated or double-slitted clear covers, which reportedly increased early transplant production of 'Travis' sweetpotato by 8 to $12 \mathrm{~d}$ over black polyethylene mulch controls (Porter, 1991).

In Louisiana, total plant production in 1992 and 1994 was increased $(P \leq 0.05)$ by BTC treatment (Table 1). In 1992, a total of 1603 and 425 transplants were cut in BTC treatment beds and control beds of 'Beauregard', respectively. In 1994, the difference in transplant production between BTC treatment (2155 plants) and the control (1291 plants) for both cultivars was less but still significant. Results for 'Jewel' were similar. In North Carolina, similar result were obtained for 'Beauregard', but total plant production was not affected in 'Jewel'. Our data demonstrate that: 1) BTC increased total transplant production consistently in 'Beauregard' over control treatments; and 2) BTC increased total transplant production in 'Jewel' only in Louisiana. In previous research, various clear covers did not increase total plant number relative to black polyethylene mulch controls (Porter, 1991; Walker and Randle, 1986).

In Louisiana, BTC plants of 'Beauregard' and 'Jewel' weighed $72 \%$ and $62 \%$ less, respectively, than did the controls in 1992 (data not shown); less etiolation in 1994 reduced weight differences of BTC vs. control plants to $34 \%$ or less. In North Carolina, BTC plants of both clones weighed at least $50 \%$ less than the controls in both years. In 'Travis', weight of plants under perforated or double-slitted clear covers did not differ from the no cover control (Porter, 1991).

Root yield. In Louisiana, differences in root yield were observed between treatments in two of the three plantings in 1992 and in one of the two plantings in 1994 (Table 2). In 'Beauregard', yields of U.S. no. 1 grade roots from BTC transplants were $33 \%$ to $41 \%$ (1992) and $51 \%$ (1994) less than that from control transplants; in 'Jewel', yields were $28 \%$ to $54 \%$ (1992) and 67\% (1994) less. No differences occurred in the first planting of each respective year when environmental conditions were best, i.e., adequate rainfall and moderate temperatures. A longer acclimation period in 1994 did not reduce the decline in yield of BTC transplants nor moderate the reduction in initial vine growth and full canopy development observed in all plantings in both years.

Table 1. Effect of black tunnel cover treatment on plant production of 'Beauregard' and 'Jewel' sweetpotato.

\begin{tabular}{|c|c|c|c|c|}
\hline \multirow[b]{4}{*}{ Observation } & \multicolumn{4}{|c|}{ Clone } \\
\hline & \multicolumn{2}{|c|}{ Beauregard } & \multicolumn{2}{|c|}{ Jewel } \\
\hline & \multicolumn{4}{|c|}{ Treatment $^{2}$} \\
\hline & Control & BTC & Control & BTC \\
\hline & \multicolumn{4}{|c|}{ Louisiana, 1992} \\
\hline Number of harvests & 3 & 6 & 3 & 6 \\
\hline Date of first harvest & 29 May & 1 May & 29 May & 1 May \\
\hline \multirow[t]{2}{*}{ Total number of transplants ${ }^{y}$} & $142 b^{x}$ & $534 \mathrm{a}$ & $90 \mathrm{~b}$ & $346 \mathrm{a}$ \\
\hline & \multicolumn{4}{|c|}{ Louisiana, 1994} \\
\hline Number of harvests & 3 & 4 & 3 & 4 \\
\hline Date of first harvest & 16 May & 2 May & 16 May & 2 May \\
\hline \multirow[t]{2}{*}{ Total number of transplants } & $430 \mathrm{~b}$ & $718 \mathrm{a}$ & $224 \mathrm{~b}$ & $427 \mathrm{a}$ \\
\hline & \multicolumn{4}{|c|}{ North Carolina, 1992} \\
\hline Number of harvests & 2 & 4 & 2 & 4 \\
\hline Date of first harvest & 14 July & 7 June & 17 June & 2 June \\
\hline \multirow[t]{2}{*}{ Total number of transplants } & $98 \mathrm{~b}$ & $575 \mathrm{a}$ & $283 \mathrm{a}$ & $347 \mathrm{a}$ \\
\hline & \multicolumn{4}{|c|}{ North Carolina, 1993} \\
\hline Number of harvests & 2 & 3 & 3 & 3 \\
\hline Date of first harvest & 17 June & 10 May & 1 June & 10May \\
\hline Total number of transplants & $351 \mathrm{~b}$ & $572 \mathrm{a}$ & $812 \mathrm{a}$ & $734 \mathrm{a}$ \\
\hline
\end{tabular}

${ }^{\mathrm{z}}$ Control = control bed (bare soil); BTC = black tunnel cover.

yPlants $23 \mathrm{~cm}$ in length.

${ }^{\mathrm{x}}$ Mean separation within rows and clones by LSD, $P \leq 0.05$.

Table 2. Effect of production of cuttings for transplanting under black tunnel covers on yield of 'Beauregard' and 'Jewel' sweetpotato roots.

\begin{tabular}{|c|c|c|c|c|}
\hline \multirow[b]{2}{*}{ Clone } & \multicolumn{4}{|c|}{ Yield $^{\mathrm{z}}\left(\mathrm{t} \cdot \mathrm{ha}^{-1}\right)$} \\
\hline & Treatment $^{\mathrm{y}}$ & Planting 1 & Planting 2 & Planting 3 \\
\hline & \multicolumn{4}{|c|}{ Louisiana, 1994} \\
\hline \multirow[t]{3}{*}{ Beauregard } & BTC & $13.9 \mathrm{a}^{\mathrm{x}}$ & $11.4 \mathrm{~b}$ & $14.7 \mathrm{~b}$ \\
\hline & Control & $10.5 \mathrm{a}$ & $16.9 \mathrm{a}$ & $25.1 \mathrm{a}$ \\
\hline & $\operatorname{LSD}_{0.05}$ & 3.5 & 3.6 & 7.2 \\
\hline \multirow[t]{4}{*}{ Jewel } & BTC & $12.1 \mathrm{a}$ & $7.0 \mathrm{~b}$ & $12.0 \mathrm{~b}$ \\
\hline & Control & $11.3 \mathrm{a}$ & $15.1 \mathrm{a}$ & $16.6 \mathrm{a}$ \\
\hline & $\mathrm{LSD}_{0.05}$ & 3.8 & 4.9 & 4.1 \\
\hline & \multicolumn{4}{|c|}{ Louisiana, 1994} \\
\hline \multirow[t]{3}{*}{ Beauregard } & BTC & $14.1 \mathrm{a}$ & $5.2 \mathrm{~b}$ & --- \\
\hline & Control & $16.4 \mathrm{a}$ & $10.7 \mathrm{a}$ & --- \\
\hline & $\mathrm{LSD}_{0.05}$ & 5.1 & 4.9 & --- \\
\hline \multirow[t]{4}{*}{ Jewel } & BTC & --- & $2.7 \mathrm{~b}$ & --- \\
\hline & Control & --- & $8.1 \mathrm{a}$ & --- \\
\hline & $\operatorname{LSD}_{0.05}$ & --- & 4.9 & --- \\
\hline & \multicolumn{4}{|c|}{ North Carolina, 1992} \\
\hline \multirow[t]{3}{*}{ Beauregard } & BTC & $24.5 \mathrm{a}$ & $17.6 \mathrm{~b}$ & $23.6 \mathrm{a}$ \\
\hline & Control & $22.3 \mathrm{a}$ & $32.3 \mathrm{a}$ & $13.1 \mathrm{~b}$ \\
\hline & $\mathrm{LSD}_{0.05}$ & 10.7 & 6.0 & 8.3 \\
\hline \multirow[t]{4}{*}{ Jewel } & BTC & $16.1 \mathrm{a}$ & $19.0 \mathrm{a}$ & $7.8 \mathrm{a}$ \\
\hline & Control & $24.2 \mathrm{a}$ & $21.9 \mathrm{a}$ & $5.0 \mathrm{a}$ \\
\hline & $\operatorname{LSD}_{0.05}$ & 18.8 & 7.0 & 9.3 \\
\hline & \multicolumn{4}{|c|}{ North Carolina, 1993} \\
\hline \multirow[t]{3}{*}{ Beauregard } & BTC & $24.7 \mathrm{a}$ & $19.2 \mathrm{a}$ & $24.1 \mathrm{~b}$ \\
\hline & Control & $25.9 \mathrm{a}$ & $15.4 \mathrm{a}$ & $34.0 \mathrm{a}$ \\
\hline & $\mathrm{LSD}_{0.05}$ & 13.2 & 4.9 & 7.7 \\
\hline \multirow[t]{3}{*}{ Jewel } & BTC & $23.4 \mathrm{a}$ & $6.4 \mathrm{a}$ & $16.7 \mathrm{a}$ \\
\hline & Control & $30.9 \mathrm{a}$ & $5.9 \mathrm{a}$ & $18.2 \mathrm{a}$ \\
\hline & $\operatorname{LSD}_{0.05}$ & 9.6 & 1.8 & 8.9 \\
\hline
\end{tabular}

${ }^{2}$ U.S. no. 1 (roots 5.1 to $8.9 \mathrm{~cm}$ diameter and 7.6 to $22.9 \mathrm{~cm}$ long).

${ }^{\mathrm{y}} \mathrm{Control}=$ transplants from control beds; $\mathrm{BTC}=$ transplants from black tunnel cover.

${ }^{x}$ Mean separation within locations, years, plantings, and clones by LSD, $P \leq 0.05$.

In North Carolina, differences were observed between treatments in the second and/ or third plantings in each year (Table 1). Yield reductions for 'Beauregard' BTC transplants ranged from $45 \%$ in 1992 (second planting) to $29 \%$ in 1993 (third planting) in comparison with controls. In 1992 and 1993, BTC treatment did not reduce yield in 'Jewel'. Results in North Carolina were similar to those in Louisiana for the first planting, i.e., yield was not affected by BTC in either clone. Results dif- fered for the second and third plantings; BTC treatment did not reduce yield of 'Jewel' and yield increased $45 \%$ in 'Beauregard' in the third transplanting in 1992. Increased yields in 'Beauregard' are in part explained by an apparent increased survival of BTC transplants in this field planting; concomitantly, these plants appeared to be less vigorous in the field than were control plants, as observed in Louisiana. We did not investigate the de-etiolation process in sweetpotato. The prime effect of 
light on plant organ development is to accelerate all phases of the division-enlargementmaturation sequence (Smith, 1975). Walker and Randle (1986) found that clear row covers did not alter yield over no cover controls in one early season yield trial. We know of no yield data for late season transplants grown under clear covers.

Black tunnel covers increase the number and earliness of transplants in comparison with bare ground production. However, clones may respond differently in different environments. Yield of early season BTC transplants was consistently similar to that of controls, implying a potential value in this method for early season transplantings. However, results were inconsistent with later transplanting dates; BTC transplants did not always yield at normal levels. This fact limits the value of this method.

\section{Literature Cited}

Boudreaux, J.E. 1994. Commercial vegetable production recommendations. Louisiana Coop. Ext. Serv. Publ. 2433.

La Bonte, D.R. and M.J. Cannon. 1997. Production and utilization of sweetpotato in the United States, p. 29-32. In: D.R. La Bonte, M. Yamashita, and H. Mochida (eds.). In: Proc. of Intl. Workshop on Sweetpotato Production Sys- tem toward the $21^{\text {st }}$ Century, Miyakonojo, Miyazaki, Japan.

Porter, W.C. 1991. Bed covers alter temporal distribution of production of sweetpotato transplants. HortScience 26:252-253.

Smith, H. 1975. The photocontrol of seedling development, p. 139-157. In: Phytochrome and photomorphogenesis. McGraw-Hill Co., Maidenhead, U.K.

Walker, D.W. and W.M. Randle. 1986. Influence of row covers, mulch, and bedding dates on early production of sweet potato transplants. HortScience 21:1354-1356.

Wilson, L.J. and C.W. Averre. 1989. Growing and marketing quality sweet potatoes. North Carolina Agr. Ext. Serv. No. AG-09. 